\title{
ANALYSIS OF THE PHYSICAL HOME ENVIRONMENT AND COMMUNITY BEHAVIOR TOWARDS INCIDENCE OF DENGUE HEMORRHAGIC FEVER IN RIAU PROVINCE
}

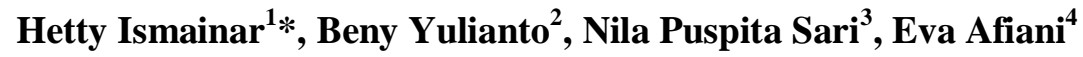

1. Department of Public Health/ Study Program Magister of Public Health, STIKes Hang Tuah Pekanbaru Riau, Pekanbaru-Indonesia

2. Department of Public Health/ Study Program Magister of Public Health, STIKes Hang Tuah Pekanbaru Riau, Pekanbaru-Indonesia

3. Department of Public Health/ Study Program Magister of Public Health, STIKes Hang Tuah Pekanbaru Riau, Pekanbaru-Indonesia

4. Department of Public Health/ Study Program Magister of Public Health, STIKes Hang Tuah Pekanbaru Riau, Pekanbaru-Indonesia

*Correspondence: Hetty Ismainar | STIKes Hang Tuah Pekanbaru Riau | ismainarhetty@yahoo.co.id

\begin{abstract}
Introduction: Dengue Hemorrhagic Fever (DHF) is still a health problem in Meranti Islands Regency. There has been an increase of $15-25 \%$ of cases every year since 2017-2019. The purpose of this study is to determine the correlation between the physical home environment and community behavior towards DHF incidence which include: ventilation, air temperature, water reservoirs, knowledge, and attitudes.

Method: It was observational analytic with a cross-sectional design. This research was conducted for three months (February-April 2020). The research subject was 92 samples were selected by the purposive sampling technique. The research instrument was a structured questionnaire and observation sheet. Data analysis using Chi-square test.

Results: There were 49 (53.3\%) cases of DHF with the physical home environment that was not following the health standards, namely: ventilation ( $\mathrm{bad}=70.7 \%)$, air temperature $(\mathrm{bad}=77.2 \%)$, water reservoirs $($ bad $=59.8 \%)$, knowledge (low $=55,4 \%$ ), and attitude (negative $=55.4 \%$ ). There was a significant correlation between ventilation $(\mathrm{p}=0,002)$, air temperature $(p=0,020)$, water reservoirs $(p=0,027)$, knowledge $(p=0,008)$, and attitudes $(p=0,000)$ toward incidence of DHF (p-value <0.05).

Conclusion: The physical home environment and community behavior are related to DHF incidence. Good coordination between health promotion team, local government in providing health education, socialization of healthy homes by empowering local communities.
\end{abstract}

Keywords: Community behavior, Dengue Hemorrhagic Fever, Physical home environment.

Received November 29, 2021; Accepted December 30, 2021

\section{INTRODUCTION}

Dengue Hemorrhagic Fever (DHF) is an infectious disease caused by the dengue virus and is transmitted through the bite of the Aedes aegypti (Ghina, 2017). Dengue is an acute viral infection with potentially fatal complications. The first clinically recognized epidemics of dengue occurred almost simultaneously in Asia, Africa, and North America in the 1780s. (Gupta, 2012). This DHF disease was first reported in Indonesia in 1968 in Jakarta and Surabaya with 48 sufferers and a mortality rate of $41.3 \%$ (Gina, 2017).

Almost all regions in Indonesia suffer from DHF. In Indonesia, the number of dengue cases reported in 2019 was 138,127 cases with an Incident Rate of 51.48 cases per 100,000 population, while the target was < 49 cases per 100,000 population. Riau Province is still at an incidence of 59.9 cases per 100,000 population and is one of the 23 provinces in Indonesia that did not meet the target. Meranti Islands is one of the regencies in Riau province that experiences an increase in dengue cases every year. In 2013 there were 98 cases, in 2014 it was 118 cases and in 2015 it increased to 254 cases (Dinkes, 2019, Ministry of Health 2019)

This disease is related to environmental conditions and people's behavior. Environmental conditions greatly affect the spread of the Aedes aegypti mosquito around us. Risk factors associated with DHF include behavior, temperature, humidity, rainfall, altitude, the presence of water reservoirs, and mosquito 
breeding places. DHF is naturally influenced by ecological status with several physical environmental factors. The related physical environment is the type of water reservoir, altitude, rainfall, wind speed, air temperature and humidity, biological environment, and social environment (DIT.JEN. PP \& PL, 2007), Prasetyani, 2015

The results of the initial survey conducted in Banglas Village, Meranti Regency, found that the houses looked damp, the garbage was not managed properly, rainwater collections used jars made of cement and were not closed, the ventilation of the house was not good, the lighting in the house was not good, and the environment their house looks very dirty. This condition is caused by the lack of public knowledge about the importance of keeping the environment clean, besides that, the attitude of the people who are less concerned also illustrates that the behavior of the people in the area is still lacking. Based on the initial survey, the researchers wanted to know the relationship between the physical environment of the house and the behavior of the community with the incidence of DHF.

\section{METHOD}

It was an observational study with a cross-sectional design. This research was conducted for three months (February-April 2020). The population was 1645 heads of household. 92 respondents participated selected by purposive sampling technique. The research location is in Banglas Village, Meranti Regency, Riau. The dependent variable is the incidence of DHF, the independent variables are the physical environment of the house and the behavior of the community, namely: ventilation, air temperature, water reservoirs, knowledge, and attitudes. For the physical environment of the house, researchers conducted field observations. Ventilation indicator with an eligible category if ventilation $>15 \%$. The air temperature with a good category of $25^{\circ} \mathrm{C}-28^{\circ} \mathrm{C}$. Water reservoirs good category if they are available and closed. As for the variables of knowledge and attitudes using a structured questionnaire that has been tested for validity and reliability. A total of 20 questions using an ordinal scale. Data were analyzed by univariate and bivariate with chi-square test with 95\% confidence interval. The Ethics Committee for Health Research, STIKes Hang Tuah Pekanbaru, issued ethical clearance for this study (No. 0209/KEPK/STIKes-HTP/V/2020). Each participant signed written informed consent.

\section{RESULTS}

Characteristics of respondents seen from the education level. The majority of low education $57(61.9 \%)$, namely Elementary School 20 (21.7\%) and Junior High School 37(40.2\%). Meanwhile, only 35 (37.1\%) have higher education, with 33 (35.9\%) senior high school and college 2(2.2\%). The frequency distribution of univariate analysis between the independent variable and the dependent variable can be seen in Table 1 below.

Tabel 1. Frequency Distribution of Home Physical Environment, Community Behavior, and DHF Incident in Alahair Village, Meranti District, Riau 2020

\begin{tabular}{|c|c|c|c|c|}
\hline No & Variable & Category & Frequency & Percent \\
\hline \multirow[t]{2}{*}{1} & DHF incident & Yes & 49 & 53,3 \\
\hline & & No & 43 & 46,7 \\
\hline \multirow[t]{2}{*}{2} & Ventilation & Good $(>15 \%)$ & 27 & 29,3 \\
\hline & & $\operatorname{Bad}(<15 \%)$ & 65 & 70.7 \\
\hline \multirow[t]{2}{*}{3} & Air Temperature & Good $\left(25^{\circ} \mathrm{C}-28^{0} \mathrm{C}\right)$ & 21 & 22,8 \\
\hline & & $\mathrm{Bad}\left(<25^{\circ} \mathrm{C}>28^{\circ} \mathrm{C}\right)$ & 71 & 77,2 \\
\hline \multirow[t]{2}{*}{4} & Water reservoirs & Yes & 27 & 40,2 \\
\hline & & No & 55 & 59,8 \\
\hline \multirow[t]{2}{*}{5} & Knowledge & High $(66-100 \%)$ & 41 & 44,6 \\
\hline & & Low $(\leq 65 \%)$ & 51 & 55,4 \\
\hline \multirow[t]{2}{*}{6} & Attitude & Positive & 41 & 44,6 \\
\hline & & Negative & 51 & 55,4 \\
\hline & Total & & 92 & 100 \\
\hline
\end{tabular}

Table 1 showed that there is $53.3 \%$ incidence rate of DHF. Bad ventilation $70.7 \%$, bad air temperature $77.2 \%$, water reservoirs that do not meet standards $59.8 \%$, low knowledge, and negative attitude is $55.4 \%$. 
The results of the bivariate analysis of the significant correlation between the physical home environment, community behavior, and the incidence of dengue fever can be seen in Table 2 below.

Table 2. Summary of Bivariate Analysis the physical home environment and community behavior related to DHF incidence in Alahair Village, Meranti District, Riau 2020

\begin{tabular}{|c|c|c|c|c|c|c|}
\hline \multirow[b]{2}{*}{ Variable } & \multicolumn{2}{|c|}{ DHF incidence } & \multirow[b]{2}{*}{ p-value } & \multirow[b]{2}{*}{ POR } & \multicolumn{2}{|c|}{ 95\% CI } \\
\hline & Yes & No & & & Lower & Upper \\
\hline Ventilation & & & & & & \\
\hline $\operatorname{Bad}(\leq 15 \%)$ & $42(64,6 \%)$ & $23(35,4 \%)$ & $0,002 *$ & & & \\
\hline Good (>15\%) & $7(25,9 \%)$ & $20(74,1 \%)$ & & 5,217 & 1,920 & $14,1 / 8$ \\
\hline Air Temperature & & & & & & \\
\hline Good $25^{\circ} \mathrm{C}-28^{\circ} \mathrm{C}$ & $43(60,6 \%)$ & $28(39,4 \%)$ & & & & \\
\hline $\mathrm{Bad}<25^{\circ} \mathrm{C}>28^{\circ} \mathrm{C}$ & $6(28,6 \%)$ & $15(71,4 \%)$ & $0,020^{*}$ & 3,839 & 1,331 & 11,078 \\
\hline Water reservoirs & & & & & & \\
\hline $\begin{array}{l}\text { Good } \\
\text { bad }\end{array}$ & $\begin{array}{l}35(63,6 \%) \\
14(37,8 \%)\end{array}$ & $\begin{array}{l}20(36,4 \%) \\
23(62.2 \%)\end{array}$ & $0,027 *$ & 2,875 & 1,214 & 6,808 \\
\hline Knowledge & & & & & & \\
\hline $\begin{array}{l}\text { High } \\
\text { Low }\end{array}$ & $\begin{array}{l}15(36,6 \%) \\
34(66,7 \%)\end{array}$ & $\begin{array}{l}26(63,4 \%) \\
17(33,3 \%)\end{array}$ & $0,008^{*}$ & 3,467 & 1,464 & 8,208 \\
\hline Attitude & & & & & & \\
\hline $\begin{array}{l}\text { Positive } \\
\text { Negative }\end{array}$ & $\begin{array}{c}42(82,3 \%) \\
7(17,1 \%)\end{array}$ & $\begin{array}{c}9(17,6 \%) \\
34(82,9 \%)\end{array}$ & $0,000^{*}$ & 22,667 & 7,649 & 67,166 \\
\hline
\end{tabular}

Abbreviations: $\mathrm{CI}=$ Confident Interval (95\%)

Table 2 reveals that the results of statistical tests show that the five independent factors are related to the incidence of DHF with p-value $<0.05$. ventilation ( $\mathrm{p}$-value 0.002, POR 5.217), air temperature (p-value 0.020, POR 3.839), water reservoirs (p-value 0.027, POR 2.875), knowledge (p-value 0.008. POR 3.467), and attitudes (p-value 0.028, POR 22.667). POR value > 1 means that the head of the family whose physical home environment and behavior are bad/ low/ negative are at risk of developing DHF disease. The negative attitude of respondents is at the highest risk of DHF.

\section{DISCUSSION}

\section{Home Physical Environment}

In this study, the physical environment of the house is focused on three variables, namely: ventilation, air temperature, and water reservoirs. The results of statistical analysis of these three factors were a significant correlation with the incidence of DHF $(\mathrm{p}<0.05)$.

\section{Ventilation}

Ventilation in this study is the exchange of air in the house with the surrounding environment which serves to supply oxygen in to the room to maintain humidity. In this study, $70.7 \%$ of respondents had poor ventilation and were a significant correlation with the incidence of DHF ( $\mathrm{p}$-value $=0.002)$. Sholihah $(2014)$ said that ventilation has a significant effect $(\mathrm{p}$-value $=0.026)$. The study showed that ventilation is eligible if the size is $>10 \%$ of the floor area. A good measure of ventilation is the most basic DHF prevention effort because it relates to the condition or construction of the house that is occupied daily. Therefore, to avoid the community from DHF, it is necessary to educate the public about the prevention, symptoms, and management of DHF.

\section{Air Temperature}

Temperature categories that can affect the development of Aedes Egypt are divided into 2, namely good $(25 \mathrm{oC}-28 \mathrm{oC})$ and not good $(<25 \mathrm{oC}$ and $>28 \mathrm{oC})$. Temperature is an important environmental parameter in increasing vector breeding, mosquito gonotrophic cycle, bite rate, shortening the incubation period of pathogens, and prolonging the lifespan of adult mosquitoes. In addition, higher temperatures also increase the rate of larval development (Fitriana and Yudhastuti, 2018). In Banglas Village, the humidity of the house temperature is between $60-75 \%$. The home environment is in a swampy area and the air circulation is not good. There are also puddles in the front and back of the house. Ideally, the humidity should be kept in 
the range of $45 \%-64 \%$ (RH or Relative Humidity). The average temperature in the Banglas Village area during $2019-2020$ is $29.20 \mathrm{C}$ with a temperature range of $27.60 \mathrm{C}-31.70 \mathrm{C}$. This temperature is the optimum temperature for mosquito breeding.

\section{Water Reservoir}

In Banglas Village, Meranti Islands Regency, residents collect rainwater as a source of needs for drinking and cooking. On average, the residents have rainwater reservoirs in the form of barrels made of cement, large plastic buckets, drums, and plastic tubs. But most of these water reservoirs are not covered and there are mosquito larvae. There is a relationship between water reservoirs and the incidence of DHF, this study is in line with researchers Mubarokah (2012), Andini (2013) who said that water reservoirs are a risk factor for mosquito breeding and affect the incidence of DHF. In addition, from the results in the field, there are also many houses of residents who do not suffer from DHF but the condition of the water is not closed and the water is left open, this certainly increases the risk of DHF occurrences in these residents. However, they claim to use mosquito repellent which is applied to their skin every morning and night, so that even if their water area is not covered, they are still protected from mosquito bites.

\section{Community Behavior}

In this study, people's behavior is focused on two variables, namely: knowledge and attitudes. The results of statistical analysis of these two factors were associated with the incidence of DHF ( $<<0.05)$.

\section{Knowledge}

In this study, the majority of people's knowledge is still low (55.4\%). The results of this research are different from the research of Syarif (2013) which states that the knowledge of the community in Maen Village about DHF as a whole gets a score of $72.2 \%$ (good category). Another study by Wandasari (2014) said that the higher the knowledge, the better the behavior of preventing DHF $(p<0.05)$. The results of this study are in line with Rianasari's research (2016) in Mustikajaya Village, Bekasi City. Knowledge related to the incidence of DHF, the results of the chi-square test obtained $p$-value $=0.015(p \leq 0.05)$. Sholihah (2014), the test results with multiple logistic regression test stated that knowledge had a significant effect with pvalue $=0.015$ and an exponential value of 0.214 times for suffering from DHF. Health education efforts for the prevention of DHF have not been optimal, public awareness of the environment in which they live is still low.

\section{Attitude}

In this study, the majority of respondents were still negative (55.4\%) and significantly correlated to DHF incidence $(p<0.05)$. In line with research conducted by Rahmaditia (2011), Lontoh (2016), and Macpal (2011) that there is a correlation between respondents' attitudes towards dengue prevention $(p<0.05)$. The behavior will be sustainable if it is based on awareness and a positive attitude. Attitudes are not brought from birth, but attitudes can be formed from the respondent's social interactions. There is a reciprocal relationship that influences individuals to influence behavior in interacting with the environment (Notoatmodjo, 2005). It's just that in this study the majority of respondents were negative. There were still respondents who did not keep their home environment clean, they still found clothes hanging in their rooms, did not close the water reservoir tightly. Public awareness and motivation are needed to improve a clean and healthy lifestyle.

\section{CONCLUSION}

The physical home environment (ventilation, air temperature, water reservoirs) and behavior community (knowledge and attitudes) are significantly correlated to the incidence of DHF. The community of Banglas Village, Meranti Regency, Riau is expected to be able to apply a clean and healthy lifestyle in their daily lives, especially in the rainy season. Health workers must coordinate in monitoring the clean and healthy lifestyle of the community sustainably. District health officers can prioritize efforts to prevent and control dengue disease, especially in dengue endemic areas, dominant with people with low education, and areas vulnerable to dengue disease infection.

\section{ACKNOWLEDGEMENT}


We would like to thank all respondents, the Head of the Puskesmas, and the Head of the Banglas Village for their participation, and facilitators in this research.

\section{REFERENCE}

Andani, 2011. Ilmu Kesehatan Masyarakat. Yogyakarta: Nuha Medika

Departemen Kesehatan R.I. 2007. Direktorat Jenderal Pengendalian Penyakit dan Penyehatan Lingkungan (DIT.JEN. PP \& PL). Survai Entomologi Demam Berdarah Dengue, Jakarta

Dinas Kesehatan Provinsi Riau. 2019. Profil Kesehatan 2019.

Fauji, R.R. 2020. Hubungan Sanitasi Lingkungan Dan Perilaku Masyarakat Terhadap Kejadian Penyakit Demam Berdarah Dengue di Wilayah Kerja Puskesmas Dirgahayu Kabupaten Kotabaru Tahun 2020. Fakultas Kesehatan Masyarakat Banjarmasin. UNISKA. 1-8

Fitriana, B.R, Yudhastuti. R. 2018. Hubungan Faktor Suhu Dengan Kasus Demam Berdarah Dengue (DBD)

Di Kecamatan Sawahan Surabaya. The Indonesian Journal of Public Health, 13(1); 83-94. doi: 10.20473/ijph.vl13il.2018

Ghina, D.F, Anwar, C. 2017. Hubungan Faktor Lingkungan Fisik Rumah Dengan Kejadian Penyakit Demam Berdarah Dengue (DBD) Di Wilayah Puskesmas Cilacap Selatan di Kabupaten Cilacap Tahun 2016. Buletin Kesehatan Lingkungan Masyarakat. 36(1); 35-41

Gupta N, Srivastava S, Jain A, Chaturvedi UC. 2012. Dengue in India. Indian J Med Res. 136(3):373-390.

Ipa M. Laksono. A.D.2014. Analisis Potensi Promosi Pengendalian Penyakit Demam Berdarah Dengue Melalui Youtube. Buletin Penelitian Sistem Kesehatan. 2014; 17(1) 97-106

Lontoh, R.Y. Rattu, A.J.M. 2016. Kaunang.W.P.J. Hubungan Antara Pengetahuan Dan Sikap Dengan Tindakan Pencegahan Demam Berdarah Dengue (DBD) DI Kelurahan Malalayang 2 Lingkungan III. Pharmacon Jurnal Ilmiah Farmasi - UNSRAT. 5(1); 382-389

Macpal, S. D. et al. 2011. Hubungan Antara Pengetahuan dan Sikap dengan Tindakan Pencegahan Penyakit Demam Berdarah Dengue (DBD) pada Masyarakat di Kelurahan Batu Kota. Fakultas Kesehatan Masyarakat Universitas Sam Ratulangi Manado.

Mubarokah. 2013. Upaya Peningkatan Angka Bebas Jentik (ABJ) BDB Melalui Penggerakan Jumantik. Unnes Journal of Public Health. 2(3); $1-9$

Notoatmodjo, S. 2005. Promosi Kesehatan Teori dan Aplikasi. Jakarta: Rineka Cipta

Peraturan Menteri Kesehatan Republik Indonesia Nomor 1077/Menkes/Per/V/2011 Tentang Pedoman Penyehatan Udara Dalam Ruang Rumah.

Prasetyani, R.D. 2015. Faktor-Faktor yang Berhubungan dengan Kejadian Demam Berdarah Dengue. Majority.7(2); 61-66

Rahmaditia, T. 2011. Hubungan Pengetahuan dan Sikap Ibu Terhadap Tindakan Pencegahan Demam Berdarah Dengue pada Anak di Wilayah Kerja Puskesmas Tlogosari Wetan Kota Semarang.

Rianasari, Suhartono, Dharminto. 2016. Hubungan Faktor Risiko Lingkungan Fisik Dan Perilaku Dengan Kejadian Demam Berdarah Dengue Di Kelurahan Mustikajaya Kota Bekasi. Jurnal Kesehatan Masyarakat (e-Journal). 4(5); 151-159

Sholihah. Qoriatus. 2014. Hubungan Kondisi Sanitasi Lingkungan, Pengetahuan dan Tingkat Pendidikan Terhadap Kejadian Demam Berdarah Dengue (DBD) di Kelurahan Lontar Kecamatan Sambikereb Kota Surabaya. Universitas Negeri Surabaya. 219-228

Syarif. I.S, Siagian. I, E, T. Kaunang. W. P. J. 2013. Pengetahuan Masyarakat Tentang Demam Berdarah Dengue Di Desa Maen Kecamatan Likupang Timur Kabupaten Minahasa Utara. Jurnal e-Biomedik (eBM). 1(1); 349-356

Uno N, Ross TM. 2018. Dengue virus and the host innate immune response. Emerg Microbes Infect. 7(1):167. Published 2018 Oct 10. sdoi:10.1038/s41426-018-0168-0

Wandasari. N. 2014. Hubungan Pengetahuan Masyarakat Tentang Penyakit Demam Berdarah Dengue (DBD) dengan Perilaku Pencegahan Demam Berdarah Dengue (DBD) di Wilayah Kerja Puskesmas Kelurahan Tegal Alur I Jakarta Barat Tahun 2014. Forum Ilmiah.12(2); 146-155 